\title{
A Survey Analyzing Reflections of COVID-19 on Patients and Their Relatives
}

\author{
COVID-19'un Hasta ve Hasta Yakınları Üzerindeki Etkisi
}

\author{
๑ Burcu Genç Yavuz, ๑ Şahin Çolak, ๑ Ramazan Güven* • • Ayşegül Ürün** , \\ ๑ Dilay Satılmış***, ๑ ibrahim Altundağ
}

University of Health Sciences Turkey, Haydarpaşa Numune Training and Research Hospital, Clinic of Emergency Medicine, Istanbul, Turkey

*University of Health Sciences Turkey, Kanuni Sultan Suleyman Training and Research Hospital, Clinic of Emergency Medicine, Istanbul, Turkey

${ }^{* * K a r a d e n i z ~ E r e g l i ~ S t a t e ~ H o s p i t a l, ~ C l i n i c ~ o f ~ E m e r g e n c y ~ M e d i c i n e, ~ Z o n g u l d a k, ~ T u r k e y ~}$

*** University of Health Sciences Turkey, 2.Sultan Abdulhamid Han Training and Research Hospital, Clinic of Emergency Medicine, Istanbul, Turkey

\section{Abstract}

Aim: In this study, we aimed to analyze the level of knowledge about Coronavirus disease-2019 (COVID-19) in patients and their relatives presented to the emergency department.

Methods: In this study, a 25-item questionnaire was applied to patients and their relatives. The participants were stratified into three groups as primary-secondary school, high school or university graduation. The responses were analyzed among education groups at a significant level of $p<0.05$.

Results: In this study, of the 212 participants, $62.7 \%$ were male. The proportion of the participants thinking "COVID-19 also affected younger individuals" was higher in participants having an education level of high school or higher $(p=0.009)$. The willingness to receive the vaccine was significantly high among all education levels. The idea that traditional soups and gargling with salty water prevent disease was found to be more common among participants with an education level of high school or lower $(p<0.05)$. The benefit from the opinion of the expert on media about protection against the virus was significant in participants with an education level below high school $(p<0.05)$.

Conclusion: The revision of key messages of public health specialists according to education levels will have an important role in reorganizing inaccurate knowledge in the community.

Keywords: COVID-19, survey, Coronavirus, pandemics
Öz

Amaç: Biz bu çalışmada acil servise başvuran hasta ve hasta yakınlarının Koronavirüs hastalığı-2019 (COVID-19) ile ilgili bilgi düzeylerini analiz etmeyi amaçladık.

Yöntemler: Bu çalışmada hasta ve hasta yakınlarına 3'lü likert tip ölçeğe uygun hazırlanan 25 soru yöneltildi. Katılımcılar ilkokulortaokul, lise ve üniversite eğitim durumlarına göre 3 gruba ayrıldı. Eğitim grupları arasında sorulara verilen yanıtlar $p<0,05$ anlamlılık düzeyine göre analiz edildi.

Bulgular: Bu çalışmada 212 katılımcının \%62,7'si erkekti. Katılımcıların eğitim durumuna göre cevapları incelediğimizde; COVID-19 enfeksiyonundan gençlerin de etkilendiğini düşünme oranı lise ve üzeri mezun grubunda daha yüksekti $(p=0,009)$. COVID-19 aşısı yaptırma isteği ise tüm eğitim gruplarında anlamlı yüksek bulunmuştur. Geleneksel çorbaların tüketiminin ve tuzlu su ile gargara yapılmasının hastalığı önlediği fikri ise yine lise altı eğitim grubunda anlamlı bulunmuştur $(p<0,05)$. Ekranlara çıkan uzman/doktorların virüsten korunmak için görüşlerinden faydalanma ise lise altı grupta daha anlamlı çıkmıştır $(p<0,05)$.

Sonuç: Halk sağlığı uzmanlarının bilgilendirme mesajlarını eğitim gruplarına göre de revize etmesi toplumdaki yanlış ya da eksik bilgilerin düzeltilmesinde etkin rol oynayacaktır.

Anahtar Sözcükler: COVID-19, anket, Coronavirüs, pandemi
Address for Correspondence/Yazışma Adresi: Burcu Genç Yavuz, University of Health Sciences Turkey, Haydarpaşa Numune Training and Research Hospital Clinic of, Department of Emergency Medicine, Istanbul, Turkey E-mail: drbgenc@gmail.com ORCID: orcid.org/0000-0001-6693-5288 Received/Geliş Tarihi: 28.10.2020 Accepted/Kabul Tarihi: 01.01.2021
'Copyright 2021 by The Medical Bulletin of istanbul Haseki Training and Research Hospital The Medical Bulletin of Haseki published by Galenos Yayınevi. ${ }^{\circ}$ Telif Hakkı 2021 istanbul Haseki Eğitim ve Araştırma Hastanesi Haseki Tıp Bülteni, Galenos Yayınevi tarafından yayınlanmıştır. 


\section{Introduction}

The severe acute respiratory syndrome coronavirus-2 (SARS-CoV-2) first emerged with findings of viral pneumonia in a group of patients at Wuhan Province, China (1). The Coronavirus disease-2019 (COVID-19), which was initially defined in a small group of patients, affected the whole Wuhan Province and the whole world thereafter (2). Currently, the COVID-19 has a mortality rate ranging from $1 \%$ to $5 \%$ (3). Although the mortality rate was lower when compared to SARS-CoV and Middle East respiratory syndrome coronavirus (MERS-CoV) from betacoronavirus family (10\% and $37 \%$, respectively), it is apparent that SARS-CoV-2 affected far more people worldwide (4). Due to the rapid spread of viruses, the World Health Organization declared pandemics on January 30,2020 , and called for collaboration to fight against the virus (5).

The past experiences from outbreaks in the last two decades suggest that level of knowledge of the community is directed on prevention or disease transmission $(6,7)$. In the current pandemics, governments have issued strict measures to fight pandemics and have made efforts to improve public awareness regarding the situation faced (6).

Despite all measures, the fight against COVID-19 is currently ongoing in Turkey as similar to the whole world. Determining the level of knowledge of patients and their relatives about virus will be beneficial in planning information meetings via public health organizations or mass media, allowing correcting false facts. Thus, in this study, we aimed to analyze the level of knowledge about COVID-19 disease in patients and their relatives presented to the emergency department (ED).

\section{Materials and Methods}

This study was conducted on patients and their relatives (aged $>18$ years) who presented to ED between May 15t, 2020 and May 30 ${ }^{\text {th }}, 2020$. The participants declining participation, participants with incomplete data, participants lacking communication skills and participants requiring prompt intervention were excluded from this study. Thus, the final analysis included data from 212 participants. The items in the questionnaire were designed to identify the community's perception to COVID-19 by considering the public agenda. The first part of the questionnaire was prepared to collect data regarding sociodemographic characteristics of the participants while the second part to measure the level of knowledge about COVID-19. The questionnaire was rated using a 3-items Likert scale, "I agree," "I don't agree" and "I am indecisive." The participants were stratified into three groups according to education level as participants with primary-secondary school, high school and university graduation. The answers were analyzed among education groups. All participants gave written informed consent. This study was approved by Haydarpaşa Numune Training and Research Hospital and conducted in accordance with tenets of the Helsinki Declaration. University of Health Sciences, Haydarpaşa Numune Training and Research Hospital (Number: 2020/52-2143 Date: 04.06.2020).

\section{Statistical Analysis}

Was carried out using IBM SPSS Statistics for Windows, Version 23.0 (IBM Corp., Armonk, NY). Descriptive analyses were presented using mean \pm SD (minimummaximum) or $n$ (\%), where appropriate. Categorical data were analyzed by the Pearson chi-square test. Cronbach's alpha coefficient was calculated for reliability analysis. A p-value of less than 0.05 was considered statistically significant.

\section{Results}

In this study, the mean age of the participants was $36.56 \pm 11.85$ years ranging from 18 to 83 years. Of the 212 participants, $62.7 \%$ were men and $37.3 \%$ were women. Of the participants, 58 participants $(27.4 \%)$ reported that they were primary or secondary school graduate, while 91 (42.9\%) were high school graduate, and 63 (29.7\%) were university or higher graduate. Of the participants, $48.1 \%$ presented to the hospital as they were ill, while $51.9 \%$ presented as patient relative (Table 1). The Cronbach alpha coefficient was calculated as 0.752 for 3-items Likert scale, indicating acceptable consistency (8).

Table 2-4 presents a comparison of responses of the participants according to education level. The findings obtained in this study showed that there were no significant differences among groups regarding responses to "this infection was transmitted by bats," "smoking aggravates the infection," "I will have the vaccine if

\begin{tabular}{|l|l|l|}
\hline \multicolumn{4}{|l|}{ Table 1. General characteristics of participants } \\
\hline & N & $\%$ \\
\hline Age (years). mean \pm SD/min-max & $36.56+11.85$ & $18-83$ \\
\hline Gender & & \\
\hline Male & 133 & 62.7 \\
\hline Female & 79 & 37.3 \\
\hline Education & & \\
\hline Primary-secondary school & 58 & 27.4 \\
\hline High school-college & 91 & 42.9 \\
\hline University or higher & 63 & 29.7 \\
\hline Cause of presentation & & \\
\hline Patient & 102 & 48.1 \\
\hline Patient's relative & 110 & 51.9 \\
\hline SD: Standard deviation, Min: Minimum, Max: Maximum & \\
\hline
\end{tabular}


it is available in Turkey" $(p=0.209, p=0.116, p=0.059$, respectively). The percent of the participants responding as "I don't agree" to the item "This infection does not affect younger individuals" was higher in participants with high school or university graduation than those with primary-secondary school graduation $(p=0.009)$. It was seen that there was no significant difference among groups regarding responses to items "COVID-19 is a biological weapon," "Turkey is successful in the fight against the virus," and "stay at Home campaign is successful in Turkey" $(p=0.168, p=0.338, p=0.059$, respectively). The percent of the participants responding as "I don't agree" to the items "The infectivity of virus is eradicated by Beyran soup" and "Gargling with salty water prevents ascending of the virus to lungs" was higher in participants with high school or university graduation than participants with primary-secondary school graduation ( $p<0.001, p<0.001$, respectively). It was seen that there was no significant difference according to education level regarding responses to the items on the use of a mask or hand disinfectant ( $p=0.657, p=0.207$, respectively). The percent of the participants responding as "I agree" to the item "I benefit from opinions of experts/clinicians on TV" was higher in the group with primary-secondary school graduation than remaining groups $(p=0.041)$. It was seen that the responses to the items "I approve broadcast with experts in the field," "The TV programs prompt unnecessary fear rather than informing people" and "I find the statement of health ministry as reliable and sufficient" were comparable according to education

Table 2. Comparison of responses according to educational level

\section{Questions}

This infection is transmitted from bats.

I don't agree

I am indecisive

I do agree

This infection does not affect younger individuals.

I don't agree

I am indecisive

I do agree

Smoking aggravates the infection.

I don't agree

I am indecisive

I do agree

I will receive if the vaccine is available in Turkey.

I don't agree

I am indecisive

I do agree

COVID-19 is a biological weapon.

I don't agree

I am indecisive

I do agree

Turkey is successful in the fight against the virus.

I don't agree

I am indecisive

I do agree

"Stay at Home" campaign is successful in Turkey

I don't agree

I am indecisive

I do agree

Data are presented as $n(\%)$. Pearson chi-square test.

COVID-19: Coronavirus disease-2019

\begin{tabular}{|c|c|c|c|}
\hline \multicolumn{3}{|l|}{ Education } & \multirow[b]{2}{*}{ p } \\
\hline $\begin{array}{l}\text { Primary-secondary } \\
\text { school }\end{array}$ & $\begin{array}{l}\text { High school or } \\
\text { college }\end{array}$ & $\begin{array}{l}\text { University or } \\
\text { higher }\end{array}$ & \\
\hline $16(27.6)$ & $35(38.5)$ & $19(30.2)$ & 0.209 \\
\hline $33(56.9)$ & $34(37.4)$ & $31(49.2)$ & \\
\hline $9(15.5)$ & $22(24.2)$ & $13(20.6)$ & \\
\hline $35(60.3)$ & $72(79.1)$ & $54(85.7)$ & 0.009 \\
\hline $18(31)$ & $15(16.5)$ & $9(14.3)$ & \\
\hline $5(8.6)$ & $4(4.4)$ & $0(0)$ & \\
\hline $7(12.1)$ & $5(5.5)$ & $1(1.6)$ & 0.116 \\
\hline $8(13.8)$ & $14(15.4)$ & $6(9.5)$ & \\
\hline $43(74.1)$ & $72(79.1)$ & $56(88.9)$ & \\
\hline $7(12.1)$ & $6(6.6)$ & $0(0)$ & 0.059 \\
\hline $21(36.2)$ & $33(36.3)$ & $20(31.7)$ & \\
\hline $30(51.7)$ & $52(57.1)$ & $43(68.3)$ & \\
\hline $10(17.2)$ & $13(14.3)$ & $14(22.2)$ & 0.168 \\
\hline $23(39.7)$ & $32(35.2)$ & $30(47.6)$ & \\
\hline $25(43.1)$ & $46(50.5)$ & $19(30.2)$ & \\
\hline $4(6.9)$ & $7(7.7)$ & $1(1.6)$ & 0.338 \\
\hline $7(12.1)$ & $18(19.8)$ & $13(20.6)$ & \\
\hline $47(81)$ & $66(72.5)$ & $49(77.8)$ & \\
\hline $8(13.8)$ & $11(12.1)$ & $4(6.3)$ & 0.059 \\
\hline $6(10.3)$ & $20(22)$ & $20(31.7)$ & \\
\hline $44(75.9)$ & $60(65.9)$ & 39 (61.9) & \\
\hline
\end{tabular}


level ( $p=0.647, p=0.998, p=0.189$, respectively). There was no significant difference in the percent of awareness about 14-Rules and adherence to 14-Rules according to education levels $(p=0.170)$. No significant relationship was found between education level and item "I am aware of Advisory Board members and I find them sufficient" $(p=0.398)$. There were differences in rates of fear from virus or think that virus is overestimated according to education level ( $p=0.167, p=0.557$, respectively). It was seen that majority of participants in each education level reported that healthcare providers worked unselfishly during pandemics $(p<0.001)$.

\section{Discussion}

By December 2019, initially in China and worldwide thereafter, COVID-19 has become one of the most common topics of discussion in both the scientific community and media, including mass media and social media. During this period, some limitations in public life have been instituted in Turkey and curfew was declared

\begin{tabular}{|c|c|c|c|c|}
\hline & Education & & & \\
\hline Questions & $\begin{array}{l}\text { Primary- } \\
\text { secondary } \\
\text { school }\end{array}$ & $\begin{array}{l}\text { High school or } \\
\text { college }\end{array}$ & $\begin{array}{l}\text { University or } \\
\text { higher }\end{array}$ & p \\
\hline \multicolumn{5}{|c|}{$\begin{array}{l}\text { The infectivity of the virus is eradicated by soup from the head and foot of } \\
\text { sheep }\end{array}$} \\
\hline I don't agree & $21(36.2)$ & $56(61.5)$ & $50(79.4)$ & $<0.001$ \\
\hline I am indecisive & $26(44.8)$ & $25(27.5)$ & $12(19)$ & \\
\hline I do agree & $11(19)$ & $10(11)$ & $1(1.6)$ & \\
\hline \multicolumn{5}{|c|}{ The infectivity of the virus is eradicated by Beyran soup } \\
\hline I don't agree & $21(36.2)$ & $56(61.5)$ & $48(76.2)$ & $<0.001$ \\
\hline I am indecisive & $29(50)$ & $27(29.7)$ & $14(22.2)$ & \\
\hline I do agree & $8(13.8)$ & $8(8.8)$ & $1(1.6)$ & \\
\hline \multicolumn{5}{|c|}{ Gargling with salty water prevents ascending of the virus to the lungs } \\
\hline I don't agree & $20(34.5)$ & $48(52.7)$ & $43(68.3)$ & $<0.001$ \\
\hline I am indecisive & $18(31)$ & $22(24.2)$ & $16(25.4)$ & \\
\hline I do agree & $20(34.5)$ & $21(23.1)$ & $4(6.3)$ & \\
\hline \multicolumn{5}{|c|}{ Viral spread is decreased by wearing a mask } \\
\hline I don't agree & $2(3.4)$ & $7(7.7)$ & $2(3.2)$ & 0.657 \\
\hline I am indecisive & $6(10.3)$ & $8(8.8)$ & $8(12.7)$ & \\
\hline I do agree & $50(86.2)$ & $76(83.5)$ & $53(84.1)$ & \\
\hline \multicolumn{5}{|c|}{ Viral spread is decreased using hand disinfectants } \\
\hline I don't agree & $4(6.9)$ & $2(2.2)$ & $0(0)$ & 0.207 \\
\hline I am indecisive & $7(12.1)$ & $11(12.1)$ & $10(15.9)$ & \\
\hline I do agree & $47(81)$ & $78(85.7)$ & $53(84.1)$ & \\
\hline \multicolumn{5}{|c|}{ I benefit from the opinions of experts/clinicians on TV programs } \\
\hline I don't agree & $5(8.6)$ & $14(15.4)$ & $6(9.5)$ & 0.041 \\
\hline I am indecisive & $3(5.2)$ & $18(19.8)$ & $13(20.6)$ & \\
\hline I do agree & $50(86.2)$ & $59(64.8)$ & $44(69.8)$ & \\
\hline \multicolumn{5}{|c|}{ I approve TV programs involving experts in the field. } \\
\hline I don't agree & $6(10.3)$ & $9(9.9)$ & $5(7.9)$ & 0.647 \\
\hline I am indecisive & $5(8.6)$ & $15(16.5)$ & $11(17.5)$ & \\
\hline I do agree & $47(81)$ & $67(73.6)$ & $47(74.6)$ & \\
\hline \multicolumn{5}{|c|}{ TV programs prompt unnecessary fear rather than informing people } \\
\hline I don't agree & $25(43.1)$ & $40(44)$ & $29(46)$ & 0.998 \\
\hline I am indecisive & $15(25.9)$ & $24(26.4)$ & $16(25.4)$ & \\
\hline I do agree & $18(31)$ & $27(29.7)$ & $18(28.6)$ & \\
\hline
\end{tabular}


Table 4. Comparison of responses according to educational level

\begin{tabular}{|c|c|c|c|c|}
\hline & Education & & & \\
\hline Questions & $\begin{array}{l}\text { Primary- } \\
\text { secondary } \\
\text { school }\end{array}$ & $\begin{array}{l}\text { High School or } \\
\text { College }\end{array}$ & $\begin{array}{l}\text { University or } \\
\text { higher }\end{array}$ & p \\
\hline \multicolumn{5}{|c|}{ I find the statement of Ministry of Health as reliable and sufficient } \\
\hline I don't agree & $9(15.5)$ & $13(14.3)$ & $2(3.2)$ & 0.189 \\
\hline I am indecisive & $15(25.9)$ & $24(26.4)$ & $17(27)$ & \\
\hline I do agree & $34(58.6)$ & $54(59.3)$ & $44(69.8)$ & \\
\hline \multicolumn{5}{|c|}{ I am aware of 14-Rules and try to adhere } \\
\hline I don't agree & $8(13.8)$ & $4(4.4)$ & $3(4.8)$ & 0.170 \\
\hline I am indecisive & $6(10.3)$ & $8(8.8)$ & $4(6.3)$ & \\
\hline I do agree & $44(75.9)$ & $79(86.8)$ & $56(88.9)$ & \\
\hline \multicolumn{5}{|c|}{ I am aware of the Advisory Board members and I find them sufficient } \\
\hline I don't agree & $12(20.7)$ & $9(9.9)$ & $7(11.1)$ & 0.398 \\
\hline I am indecisive & $12(20.7)$ & $20(22)$ & $15(23.8)$ & \\
\hline I do agree & $34(58.6)$ & $62(68.1)$ & $41(65.1)$ & \\
\hline \multicolumn{5}{|c|}{ I feel fear about the virus transmission to me } \\
\hline I don't agree & $10(17.2)$ & $11(12.1)$ & $2(3.2)$ & 0.167 \\
\hline I am indecisive & $8(13.8)$ & $14(15.4)$ & $11(17.5)$ & \\
\hline I do agree & $40(69)$ & $66(72.5)$ & $50(79.4)$ & \\
\hline \multicolumn{5}{|c|}{ I think the virus is overestimated } \\
\hline I don't agree & $29(50)$ & $51(56)$ & $39(61.9)$ & 0.557 \\
\hline I am indecisive & $10(17.2)$ & $19(20.9)$ & $10(15.9)$ & \\
\hline I do agree & $19(32.8)$ & $21(23.1)$ & $14(22.2)$ & \\
\hline \multicolumn{5}{|c|}{ I think healthcare providers worked unselfishly during the pandemic } \\
\hline I don't agree & $6(10.3)$ & $3(3.3)$ & $0(0)$ & $<0.001$ \\
\hline I am indecisive & $2(3.4)$ & $8(8.8)$ & $4(6.3)$ & \\
\hline I do agree & $50(86.2)$ & $80(87.9)$ & $59(93.7)$ & \\
\hline
\end{tabular}

\section{Table 5. 14 Rules against the novel coronavirus risk: Coronavirus Is Not Stronger Than Measures You Take!}

1. Wash your hands frequently with soap and water for at least 20 seconds.

2. Keep a distance of at least 3 to 4 steps between people showing flu signs.

3. Cover your mouth and nose with disposable wipes during coughing or sneezing. If there is no wipe, use the inner part of your elbow.

4. Avoid close contact, such as handshaking or hugging.

5. Do not touch your hands to mouth, nose and eyes.

6. Postpone or cancel your travels abroad.

7. Isolate yourself at home for at least 14 days after returning abroad.

8. Ventilate your environments frequently.

9. Wash your clothes at 60-90 C using normal detergents.

10. Clean surfaces commonly used surfaces, such as door handles, armatures and sinks daily using water, disinfectant and detergent.

11. If you have cold symptoms, do not contact the elderly and people with chronic diseases. Do not go out without wearing a mask.

12. Do not share personnel belongings, such as a towel.

13. Consume sufficient fluid, follow a balanced diet, and pay attention to your sleep pattern.

14. If you have any complaints, such as persistent fever, cough and difficulty breathing, contact 
for all individuals of all ages during weekends and bank holidays. In addition, continuous curfew was declared for individuals aged $>65$ years and those $<20$ years; public and private areas were closed to access; distance education programs were implemented, and areas where people can be present indiscrete were closed. Mass transportation was halted and permission was warranted for crossing between provinces. Extremely strict measures, such as quarantine for individuals with contact to infected people or isolation and provision of personal requirements of suspected individuals have been taken, which we had not experienced previously. Primary protection methods were expressed as 14-Rules (Table 5) by Advisory Board and a nationwide campaign "Stay at Home" was launched (9). Obviously, in addition to measures held by governments, the community has a great mission to lower spread. Although 14-Rules explain primary measures against coronavirus risk, potential false information should be revealed and correction of this false information will be helpful in the management of the pandemics.

Studies showed that novel coronavirus has $>95 \%$ homology with bat coronavirus and $>70 \%$ phylogenetic homology with SARS-CoV (10). In a survey on 453 healthcare providers, $58.7 \%$ of the participants confirmed COVID-19 transmission from bats (11). In our survey, the majority of the participants (46.2\%) reported that they are indecisive about transmission from bats, while $40 \% 1$ of the participants reported that they are indecisive and $42.5 \%$ of participants reported that they agree to the item about being a biological weapon. The finding that there was no difference in responses according to education level in these items indicates that conspiracy theories are at the forefront for community and that community does not trust global forces and terrorist activities although coronavirus was proven to be zoonosis. Based on the results of an online survey, $23.9 \%$ of participants from USA and $18.4 \%$ from UK responded as "less likely," "likely" or "very likely" to the item "Is coronavirus a biological weapon" (12). The higher rate in our study may be because global forces and conspiracy theories are more commonly discussed in our society. Of the participants, $75.9 \%$ responded as "I don't agree" to the item "This infection does not affect younger individuals." The rate of the answer "I don't agree" to this item was higher in the participants with high school or university graduation than the participants with primarysecondary school graduation. In an online survey, 96.5\% of participants from the US and $97.1 \%$ of participants from the UK did not agree to the following statement, "Only elder individuals are affected by virus" (12). Such an idea may lead that inadequate compliance to measures against the virus and overlooking transmission risk in the society by younger individuals. The rate of participants who responded as "I don't agree" was low among lower education levels suggests that public health specialists should inform society about this issue.

In our country, it is thought that some traditional soups enhance the immune system and their consumption is increased, particularly in respiratory tract infections. Even sometimes, some clinicians recommend these soups in the lists for healthy nutrition. Traditionally, the opinion that gargling with salty water will clean oropharynx is accepted in society. In our survey, the majority of participants responded as "I don't agree" to the items "The infectivity of virus is eradicated by the soup prepared from head and foot of sheep," "The infectivity of virus is eradicated by Beyran soup" and "gargling with salty water prevents ascending of the virus to lungs" (59.9\%, 59.0\% and $52.4 \%$, respectively). When assessed according to education level, the rate of participants responded as "I don't agree" was higher among subjects with high school or university graduation than those with primarysecondary school graduation $(p<0.05)$. The commitment of individuals with primary-secondary school graduation to traditional methods may be the cause of a higher rate of "I do agree" and "I am indecisive" in this group. It is recommended that public health interventions to inform society should target info pollution circulating on TV/ video, press or social media $(12,13)$. Thus, experts should continuously state that traditional soups or gargling are not effective protective measures against the virus.

Despite the proven efficiency of vaccines in the prevention of disease and disability, there are growing concerns about anti-vaccination or vaccine hesitancy, which has become a considerable challenge worldwide (14). In a survey on childhood vaccines in Turkey, 59.7\% of the families declined all childhood vaccines, while $30.3 \%$ declined only some childhood vaccines (15). It is apparent that vaccine perception will change after coronavirus pandemics. In our survey, $50 \%$ of the participants reported that they were willing to receive the coronavirus vaccine, which did not differ according to education level. It is striking that $34.9 \%$ of participants are still indecisive about vaccination. Certainly, more information provided in public health programs will help to change minds in these indecisive individuals, and even it may offer a chance to prevent vaccine hesitancy. Trust in vaccines may be recovered in society, preventing the recurrence of many diseases associated with high morbidity and mortality.

It has been proposed that smokers are at higher risk for coronavirus during pandemics because of the harmful effects of smoking on immune and respiratory systems (16). In a survey by Klemperer et al. (16), the findings showed that to reduce the risk for COVID-19, 22.9\% and $21.9 \%$ of the participants attempted to quit tobacco or 
electronic cigar use, respectively. In our study, $80.7 \%$ of the participants stated that infection has a more severe course in smokers. Emphasizing this issue in public health programs will facilitate the prevention of smoking since $73.6 \%$ reported fear from virus transmission and $56.1 \%$ though that virus is not overestimated. When discussing the harmful effects of smoking, one should not only emphasize the increased incidence of cancer in smokers but also explain that it affects the course of infections due to its impact on the immune system.

Of the participants, $76.4 \%$ reported that government is successful in the fight against the virus and $67.5 \%$ approved that campaign Stay at Home played an effective role in reducing viral spread while $62.3 \%$ found statements of government reliable and sufficient and $84.4 \%$ reported that they are aware of 14-Rules and attempt to adhere these rules. Of the participants, $64.6 \%$ reported that they were aware of the advisory board and found the work of board sufficient. The finding that there was no difference according to education level in these items suggests that the majority of society trusts the government.

During pandemics, many television programs were on air and experts responded questions from the public. Of participants in our survey, $75.9 \%$ approved television programs with experts and $72.8 \%$ reported that they benefit from opinions of experts/clinicians on television programs. In a survey on healthcare providers, approximately $30 \%$ of the participants reported that they followed information about COVID-19 from TV, video, press or social media (11). In our study, rates above $70 \%$ on the items regarding media suggest that televisions programs have an influence on the perception of society; in fact, accurate programs can help to improve awareness in many issues in society. It was striking that the responding as "I agree" to item "I benefit from opinions of experts/clinicians on TV programs" was higher among participants with primary or secondary school graduation when compared to the remaining group $(p=0.041)$. These findings suggest that updating the content of TV programs to appeal to individuals with lower education levels will be beneficial in improving the level of knowledge of society. In an online survey, including 6,910 participants, the findings showed that designing TV programs appealing to participants with low education levels would substantially improve knowledge about COVID-19 (6).

The increased physical and verbal violence against healthcare providers is a non-negligible fact worldwide. About one-third of the healthcare providers experience physical violence at least once and more experience verbal abuse or threat throughout a professional career (17). The healthcare providers subjected to violence will experience decreased motivation, negatively influencing his/her performance and decreasing the quality of healthcare services provided (18). In the literature, the incidence of violence against healthcare providers has been reported as $0.4-91 \%$ (19). In our study, $89.2 \%$ of the participants thought that healthcare providers work unselfishly during pandemics. While $73.6 \%$ of the participants reported fear about virus transmission, healthcare providers working actively in the hot zone led an empathy and recovery of esteem to healthcare providers.

The single-center design is a major limitation of our study. Multicenter studies with more patients and relatives can make clearer observations about the level of knowledge of society on novel coronavirus. This may help revealing interventions performed and deficiencies, leading improved awareness in society. These interventions are highly important in the fight against the outbreak.

\section{Conclusion}

We aimed to analyze the reflections of the novel coronavirus in society through a questionnaire completed by patients and their relatives. It was seen that participants were indecisive about the likelihood that the virus could be a biological weapon rather than being a virus transmitted naturally. It was also observed that society is trusting to the Turkish Ministry of Health and advisory board and adheres to recommendations and statements by these organizations. Given that there is a consensus that Turkey is successful in the fight against the virus, this indicates an environment of confidence. It is obvious that TV programs can affect the level of knowledge in society. Thus, awareness will be improved by accurate messages via media, given that society takes these messages seriously.

\section{Author contributions}

Concept: B.G.Y, S.Ç., R.G., Design: B.G.Y, S.Ç., R.G., Data Collection or Processing: B.G.Y., S.Ç., R.G., A.Ü., D.S., i.A., Analysis or Interpretation: B.G.Y., S.Ç., R.G., A.Ü., D.S., I.A., Literature Search: B.G.Y., S.Ç., R.G., A.Ü., D.S., I.A., Writing: B.G.Y.

Funding and support: The authors did not apply for a specific grant for this research from any funding agency in the public commercial or non-profit sectors.

Conflict of interests: Authors declare no conflict of interest.

\section{References}

1. Liu K, Chen Y, Lin R, Han K. Clinical features of COVID-19 in elderly patients: A comparison with young and middle-aged patients. J Infect 2020;80:14-8.

2. Lian J, Jin X, Hao S, et al. Analysis of Epidemiological and Clinical Features in Older Patients With Coronavirus Disease 2019 (COVID-19) Outside Wuhan. Clin Infect Dis 2020;71:7407. 
3. Wu Z, McGoogan JM. Characteristics of and Important Lessons From the Coronavirus Disease 2019 (COVID-19) Outbreak in China: Summary of a Report of 72314 Cases From the Chinese Center for Disease Control and Prevention. JAMA 2020;323:1239-42.

4. Huang C, Wang $Y$, Li $X$, et al. Clinical features of patients infected with 2019 novel coronavirus in Wuhan, China. Lancet 2020;395:497-506.

5. World Health Organization. 2019-nCoV outbreak is an emergency of international concern. DOI: 10.4103/ijpvm. IJPVM_63_20

6. Zhong BL, Luo W, Li HM, et al. Knowledge, attitudes, and practices towards COVID-19 among Chinese residents during the rapid rise period of the COVID-19 outbreak: a quick online cross-sectional survey. Int J Biol Sci 2020;16:1745-52.

7. Person B, Sy F, Holton K, Govert B, Liang A; National Center for Inectious Diseases/SARS Community Outreach Team. Fear and stigma: the epidemic within the SARS outbreak. Emerg Infect Dis 2004;10:358-63.

8. Taber KS. The Use of Cronbach's Alpha When Developing and Reporting Research Instruments in Science Education. Available from: https://doi.org/10.1007/s11165-016-9602-2 Research in Science Education 2017.

9. Health Ministry of Republic of Turkey. Available from: https://covid19.saglik.gov.tr/ Eklenti/37663/0/covid-1914kuralafis50x70pdf.pdf?_ $\operatorname{tag} 1=9 D 07 F 364$ A8E010A62B47454F4C96064EC1F94280. 2020.

10. Singhal T. A Review of Coronavirus Disease-2019 (COVID-19). Indian J Pediatr 2020;87:281-6.
11. Bhagavathula AS, Aldhaleei WA, Rahmani J, Mahabadi MA, Bandari DK. Knowledge and Perceptions of COVID-19 Among Health Care Workers: Cross-Sectional Study. JMIR Public Health Surveill 2020;6:19160.

12. Geldsetzer P. Use of Rapid Online Surveys to Assess People's Perceptions During Infectious Disease Outbreaks: A Cross-sectional Survey on COVID-19. J Med Internet Res 2020;22:18790.

13. Zarocostas J. How to fight an infodemic. Lancet 2020;39:676.

14. Larson HJ, Jarrett C, Schulz WS, et al. Measuring vaccine hesitancy: The development of a survey tool. Vaccine 2015;33:4165-75.

15. Topçu S, Almış H, Başkan S, Turgut M, Orhon FŞ, Ulukol B. Evaluation of Childhood Vaccine Refusal and Hesitancy Intentions in Turkey. Indian J Pediatr 2019;86:38-43.

16. Klemperer EM, West JC, Peasley-Miklus C, Villanti AC. Change in Tobacco and Electronic Cigarette Use and Motivation to Quit in Response to COVID-19. Nicotine Tob Res 2020;22:1662-3.

17. Lafta RK, Falah N. Violence against health-care workers in a conflict affected city. Med Confl Surviv 2019;35:65-79.

18. World Health Orgwanization. Violence and Injury Prevention, Violence against health workers. Available from: http://www. who.int/violence_injury_preven tion/violence/workplace/ en/. 2018.

19. Franz S, Zeh A, Schablon A, et al. Aggression and violence against health care workers in Germany-a cross sectional retrospective survey. BMC Health Serv Res 2010;10:51. 